\title{
Erratum to: A prospective observational study comparing a physiological scoring system with time-based discharge criteria in pediatric ambulatory surgical patients
}

\author{
James Armstrong, BMBS $\cdot$ Helen Forrest, BScN $\cdot$ Mark W. Crawford, MBBS
}

Published online: 14 September 2015

(C) Canadian Anesthesiologists' Society 2015

\section{Erratum to: Can J Anesth/J Can Anesth \\ DOI 10.1007/s12630-015-0428-6}

In the published version, the first phrase of the introduction was incorrect and should read as follows:

Since the inception of the postanesthesia care unit (PACU) in $1923,{ }^{1}$ the question of when it is safe to discharge a patient has remained contentious.

The publisher apologizes most sincerely for this typesetting error.

The online version of the original article can be found under doi:10. 1007/s12630-015-0428-6.

J. Armstrong, BMBS $\cdot$ H. Forrest, BScN .

M. W. Crawford, MBBS ( $\square)$

Department of Anesthesia and Pain Medicine, The Hospital for

Sick Children, University of Toronto, 555 University Avenue,

Toronto, ON M5G 1X8, Canada

e-mail: mark.crawford@sickkids.ca 